\title{
Formal synthesis of the bisbenzylisoquinoline alkaloid berbamunine by asymmetric substitution of chiral organolithium compounds
}

\author{
Robert E. Gawley ${ }^{\mathrm{a}}$ and Gregory A. Smith \\ ${ }^{a}$ Department of Chemistry and Biochemistry, University of Arkansas, \\ Fayetteville, AR 72701, USA \\ ${ }^{b}$ Department of Chemistry, University of Miami, Coral Gables, FL 33124, USA \\ E-mail: bgawley@uark.edu
}

Dedicated to Professor Bill Bailey on the occasion of his $65^{\text {th }}$ birthday

\begin{abstract}
Asymmetric alkylation of enantiomeric tetrahydroisoquinolyl oxazolines was achieved with 96-97\% diastereoselectivity. Removal of the oxazoline chiral auxiliary and further transformations provide a straightforward synthesis of the two synthetic intermediates that were previously synthesized by resolution, and which comprise a formal synthesis of berbamunine by Ullman coupling.
\end{abstract}

Keywords: Oxazoline auxiliary

\section{Introduction}

The bisbenzylisoquinoline alkaloids are a class of compounds having two benzylisoquinoline subunits, which may be similar or dissimilar, joined by one or more ether bridges. One group of structurally identical bisbenzylisoquinolines, of which there are four diastereomers, is shown in Figure 1. Of these, three were first isolated from natural sources: magnoline from the leaves of Magnolia fuscata, ${ }^{1}$ berbamunine from Berberis amurensis, ${ }^{2}$ and guattegaumerine from Guatteria gaumeri,

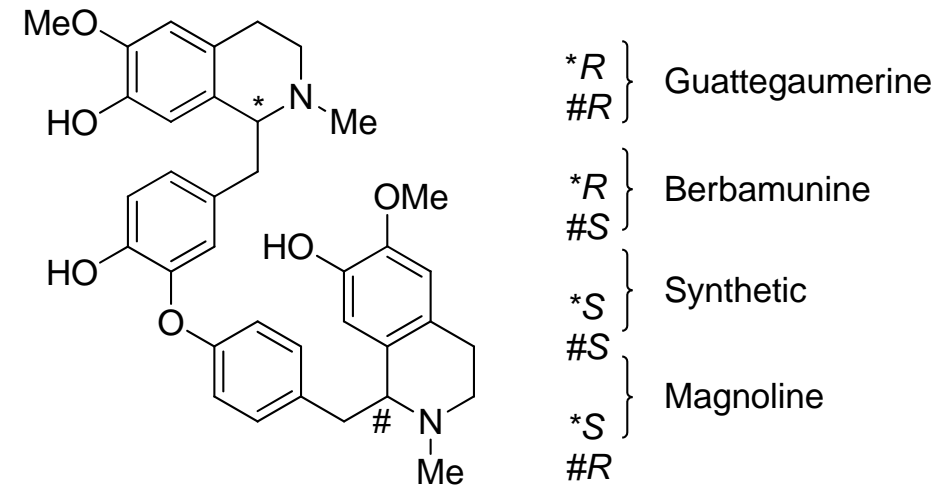

Figure 1. Stereoisomeric bisbenzylisoquinoline alkaloids. 
a medicinal plant in southeast Mexico. ${ }^{3}$ The fourth has yet to be isolated from natural sources, but has been synthesized, ${ }^{4}$ Some of the bisbenzylisoquinoline alkaloids have shown antitumor activity.

\section{Results and Discussion}

The synthesis of berbamunine by Ullman ether coupling of the two fragments $\mathbf{1}$ and 2, shown in Scheme 1, was reported by Kametani in 1969. ${ }^{4-5}$ These two fragments were obtained either by resolution of synthetic material or by modification of natural coclaurine. Our goal was simply to prepare these two species by asymmetric synthesis, as shown by the second retrosynthetic arrow. Particularly appealing is that both $\mathbf{1}$ and $\mathbf{2}$ are derived from the same compound, $\mathbf{3}$. Control of the absolute configuration is dependent on the absolute configuration of the chiral auxiliary. The pioneer in the auxiliary-mediated alkylation of tetrahydroisoquinolines using formamidines was Meyers; ${ }^{6}$ in this work, we use an oxazoline auxiliary developed in our group. ${ }^{7}$<smiles>COc1cc2c(cc1O)[C@@H](Cc1ccc(Oc3cc(C[C@@H]4c5cc(O)c(OC)cc5CCN4C)ccc3O)cc1)N(C)CC2</smiles>

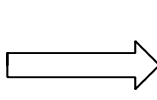<smiles>COc1cc2c(cc1OCc1ccccc1)[C@@H](Cc1ccc(OCc3ccccc3)c(Br)c1)N(C)CC2</smiles>

1<smiles>COc1cc2c(cc1OCc1ccc(O)cc1)C(Cc1ccccc1)N(C)CC2</smiles>

2<smiles>[R]Oc1ccc(CCl)cc1</smiles>

3

4a: $R=B n$

4b: $R=M O M$

Scheme 1. Retrosynthetic plan for synthesis of berbamunine.

Tetrahydroisoquinoline $\mathbf{3}$ was prepared in six routine steps, as illustrated in Scheme 2. The phenolic hydroxyl group of vanillin was protected as its benzyl ether, and the aldehyde function was then condensed with nitromethane in a Henry reaction. Reduction of the double bond and nitro groups afforded phenyethyl amine $\mathbf{5}$. Formylation of $\mathbf{5}$ was followed by Bischler-Napieralski cyclization using $\mathrm{PCl}_{5}$. Reduction of the resulting imine hydrochloride gave tetrahydroisoquinoline 3 in $20 \%$ overall yield for the 6 steps. 
<smiles>COc1cc(C=O)ccc1O</smiles>

vanillin

\author{
1. $\mathrm{NaH}, \mathrm{BnBr}(84 \%)$ \\ 2. $\mathrm{CH}_{3} \mathrm{NO}_{2}, \mathrm{HOAc}(83 \%)$ \\ 3. $\mathrm{LiAlH}_{4}(71 \%)$
}<smiles>COc1cc(CCN)ccc1OCc1ccccc1</smiles>

5

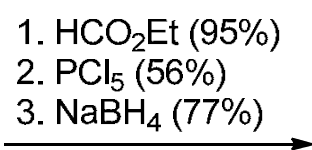

2. $\mathrm{PCl}_{5}(56 \%)$

3. $\mathrm{NaBH}_{4}(77 \%)$

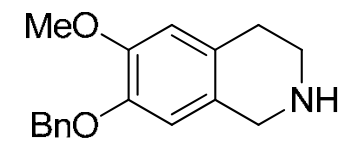

3

Scheme 2. Tetrahydroisoquinoline synthesis.

Since compounds $\mathbf{1}$ and $\mathbf{2}$ differ in their absolute configuration, enantiomeric chiral auxiliaries were appended, as illustrated in Scheme 3. Ethoxyoxazolines $S-\mathbf{6}$ and $R-\mathbf{6}$ are readily available from the corresponding oxazolidinone by O-alkylation with triethyloxonium tetrafluoroborate. ${ }^{7}$ Refluxing the 2-ethoxyoxazolines with tetrahydroisoquinoline 3 in benzene with a catalytic amount of $p$-TsOH afforded $S-7$ and $R$-7 in excellent yield.
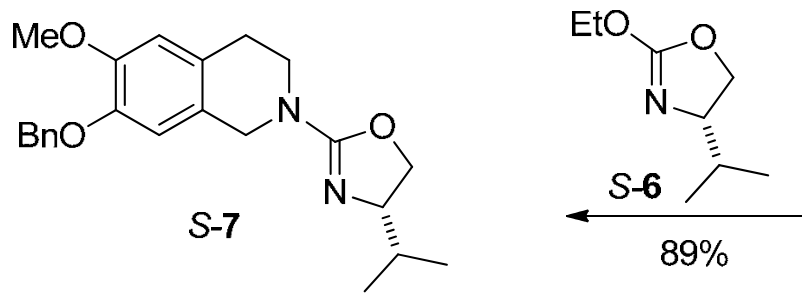<smiles>COc1cc2c(cc1OCc1ccccc1)CNCC2</smiles>
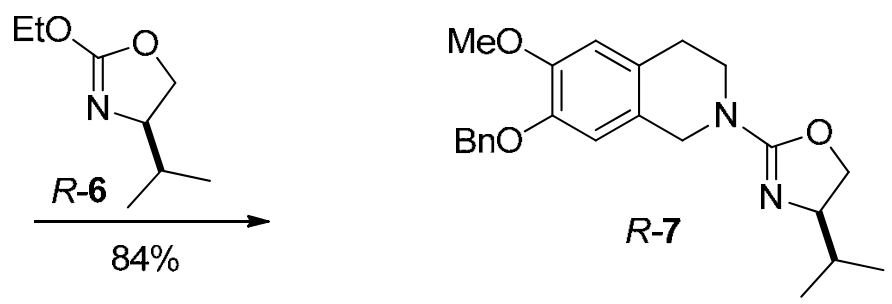

Scheme 3. Chiral auxiliary attachment.

Fragment 1 was synthesized in either of two ways, illustrated in Scheme 4, which differ only in the sequence of steps. In the first path, alkylation of S-7 with 4-benzyloxybenzyl chloride gave compound 8 in 83\% yield and 96\% diastereoselectivity. The stereoisomer ratio was determined by chiral stationary phase chromatography after removal of the oxazoline auxiliary and acylation with 1-naphthoyl chloride, which provides both the enantiomer ratio and the absolute configuration. ${ }^{8}$ Treatment of $\mathbf{8}$ with acetic formic anhydride removed the auxiliary and formylated the nitrogen in a single step, ${ }^{9}$ giving $N$-formyl tetrahydroisoquinoline 9 in 79\% yield. Reduction and bromination 
then afforded 1 in $60 \%$ yield for the two steps. Alternatively, $S-7$ could be alkylated with 3-bromo4-benzyloxybenzyl chloride in 75\% yield and 96\% diastereoselectivity. The oxazoline was removed from 10 by hydrazinolysis and the nitrogen was formylated with acetic formic anhydride to give $N$ formyltetrahydroisoquinoline $\mathbf{1 1}$ in $66 \%$ yield for the two steps. After hydrazinolysis, the enantiomer ratio, er, and absolute configuration were determined as above. Reduction then yields $\mathbf{1}$ in $86 \%$ yield. The overall yield via $\mathbf{8}$ and $\mathbf{9}$ is 39\%, and via $\mathbf{1 0}$ and $\mathbf{1 1}$ is $43 \%$, while each route requires 4 steps. The identity of this compound was established by comparison of the melting point of the free base and its di-p-tolyltartrate salt, as well as the optical rotations of each, with literature values. $^{10}$

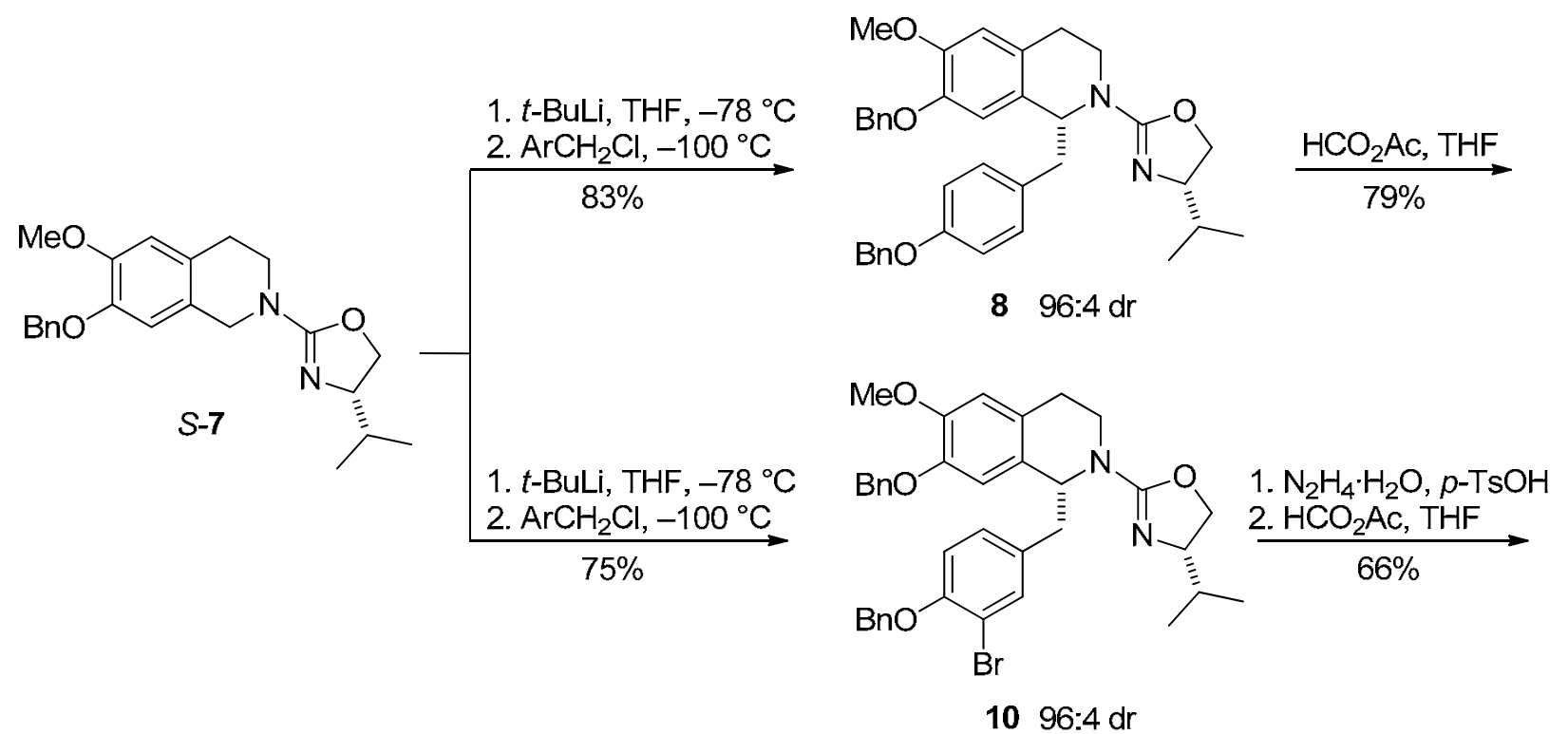<smiles>COc1cc2c(cc1OCc1ccccc1)[C@@H](Cc1ccc(OCc3ccccc3)cc1)N(C=O)CC2</smiles>

9<smiles>COc1cc2c(cc1OCc1ccccc1)[C@@H](Cc1ccc(OCc3ccccc3)c(Br)c1)N(C=O)CC2</smiles><smiles>CCCC[Mg]F</smiles>

1. $\mathrm{LiAlH}_{4}$, THF 2. $\mathrm{Br}_{2}, \mathrm{HOAC}$

$60 \%$<smiles>COc1cc2c(cc1OCc1ccccc1)[C@@H](Cc1ccc(OCc3ccccc3)c(Br)c1)N(C)CC2</smiles>

Scheme 4. Synthesis of fragment 1. 
The synthesis of fragment $\mathbf{2}$ was accomplished as shown in Scheme 5. The $R$ enantiomer of 7 was alkylated with 4-methoxymethoxybenzyl chloride in $84 \%$ yield and $97 \%$ diastereoselectivity. The stereoisomer ratio and absolute configuration were again established by hydrazinolysis and acylation with 1-naphthoyl chloride, followed by chiral stationary phase HPLC. ${ }^{8}$ Hydrazinolysis and formylation with acetic formic anhydride gave $N$-formyl tetrahydroisoquinoline 13 in $77 \%$ yield for the two steps. Reduction and deprotection afforded fragment 2 in $60 \%$ yield. The preparation of $\mathbf{2}$ therefore proceeded in 38\% overall yield for the 5 steps.
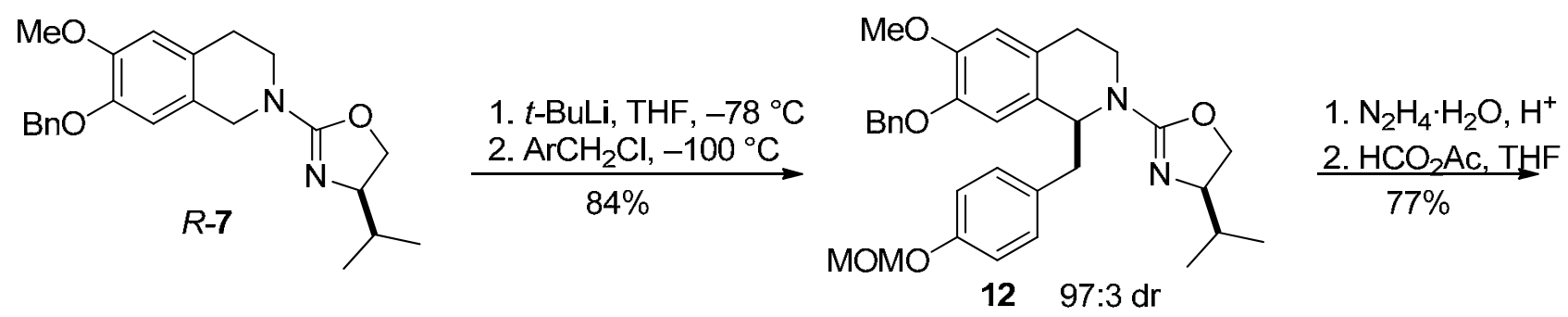<smiles>COc1ccc(CC2c3cc(OC)c(OC)cc3CCN2C=O)cc1</smiles>

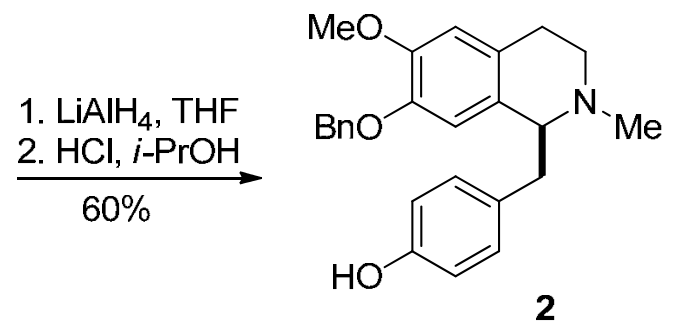

Scheme 5. Synthesis of fragment 2.

In conclusion, the asymmetric synthesis of fragments $\mathbf{1}$ and $\mathbf{2}$ constitute a formal synthesis of the bisbenzylisoquinoline alkaloid berbamunine, a route which could also be adapted to the synthesis of its diastereomers.

\section{Experimental Section}

General. Tetrahydrofuran and diethyl ether were distilled immediately prior to use from sodium benzophenone ketyl. Tetramethylethylene diamine (TMEDA) was distilled from $\mathrm{CaH}_{2}$ immediately before use. All other solvents used during the synthetic procedures were purified by distillation; other commercial reagents were used as received. All reactions were run under a nitrogen atmosphere. Infrared spectra were obtained as neat films or as a methylene chloride solution. Proton NMR spectra were recorded at either 60 or $400 \mathrm{MHz}$, and carbon NMR spectra were recorded at 20 $\mathrm{MHz}$; chemical shifts are reported in ppm, relative to TMS. Chiral stationary phase chromatography employed a Bakerbond (R)-DNBPG (covalent) Pirkle column. All melting and boiling points are reported in ${ }^{\circ} \mathrm{C}$ and are uncorrected. Radial chromatography was performed on a Harrison Research 
Model 7924 Chromatron using silica gel 60 PF254 (E. Merck) containing gypsum. Elemental analyses were performed by Atlantic Microlabs, Norcross, Georgia.

3-Methoxy-4-(benzyloxy)benzaldehyde. Vanillin (4, 30.0 g, $197.0 \mathrm{mmol}$ ) was added slowly to a stirred, cooled $\left(10^{\circ} \mathrm{C}\right)$ suspension of sodium hydride (50\% oil dispersion: $\left.10.44 \mathrm{~g}, 217.0 \mathrm{mmol}\right)$ in THF $(500 \mathrm{~mL})$. The suspension was warmed to room temperature and stirred $0.5 \mathrm{~h}$. Tetrabutylammonium iodide (3.0 g) and benzyl bromide (24.60 mL, $207.0 \mathrm{mmol}$ ) were added, the reaction refluxed $18 \mathrm{~h}$, cooled, washed with water $(2 \mathrm{x} 200 \mathrm{~mL})$ and brine $(200 \mathrm{~mL})$, the organic phase dried $\left(\mathrm{Na}_{2} \mathrm{SO}_{4}\right)$ and concentrated in vacuo. Recrystallization from $10 \% \mathrm{THF} /$ hexanes gave $40.30 \mathrm{~g}$ (84\%) of an off-white solid; mp 62-64 ${ }^{\circ} \mathrm{C}$ (lit. mp 63-65 $\left.{ }^{\circ} \mathrm{C}\right) .{ }^{11}{ }^{1} \mathrm{H} \mathrm{NMR}\left(\mathrm{CDCl}_{3}\right): 3.93$ (s, $3 \mathrm{H}), 5.24$ (s, 2H), 6.93-7.07 (m, 3H), 7.40 (bs, 5H), 9.84 (s, 1H).

1-(Benzyloxy)-2-methoxy-4-(2-nitroethenyl)benzene. A solution of the above aldehyde (20.0 g, $83.0 \mathrm{mmol})$, nitromethane $(11.0 \mathrm{~mL}, 203.0 \mathrm{mmol})$ and ammonium acetate $(7.0 \mathrm{~g}, 91.0 \mathrm{mmol})$ in glacial acetic acid $(150 \mathrm{~mL})$ was refluxed $5 \mathrm{~h}$. The hot solution was poured on to crushed ice (700g), the precipitate filtered, washed with water, air dried and recrystallized from 20\% EtOAc/hexanes to give the nitrostyrene (19.52 g, 83\%) as yellow needle-like crystals; mp 124-125 ${ }^{\circ} \mathrm{C}$ (lit. mp $\left.126-128{ }^{\circ} \mathrm{C}\right) .{ }^{12}$

2-[3-Methoxy-4-(benzyloxy)phenyl]ethylamine (5). The above nitrostyrene (21.0 g, $74.0 \mathrm{mmol}$ ) was added slowly to a stirred, cooled $\left(10^{\circ} \mathrm{C}\right)$ suspension of LAH (4.19 g, $\left.110.0 \mathrm{mmol}\right)$ in THF (300 $\mathrm{mL})$. The reaction mixture was warmed to room temperature, refluxed $16 \mathrm{~h}$, cooled, diluted with ether $(150 \mathrm{~mL})$ and quenched with water $(4 \mathrm{~mL}), 15 \% \mathrm{NaOH}(4 \mathrm{~mL})$ and water $(12 \mathrm{~mL})$. The mixture was stirred $30 \mathrm{~min}$, filtered, the filtrate washed with brine $(300 \mathrm{~mL})$, dried $\left(\mathrm{Na}_{2} \mathrm{SO}_{4}\right)$ and concentrated in vacuo. The residue was dissolved in $10 \% \mathrm{HCl}(100 \mathrm{~mL})$ and washed with ether $(2 \mathrm{x}$ $75 \mathrm{~mL}$ ). The aqueous phase was made basic and extracted with ether (3 x $100 \mathrm{~mL}$ ). The combined extracts were washed with brine $(200 \mathrm{~mL})$, dried $\left(\mathrm{Na}_{2} \mathrm{SO}_{4}\right)$ and concentrated in vacuo to give the phenethylamine (13.50 g, $71 \%$ ); mp 59-61 ${ }^{\circ} \mathrm{C}$ (lit. mp 60-62 $\left.{ }^{\circ} \mathrm{C}\right) .{ }^{13}$

$\mathbf{N - F o r m y l - 2 - [ 3 - m e t h o x y - 4 - ( b e n z y l o x y ) p h e n y l ] e t h y l ~ a m i n e . ~ A ~ s o l u t i o n ~ o f ~ p h e n e t h y l a m i n e ~} 5$ (17.35 g, $67.0 \mathrm{mmol})$ and ethyl formate $(20.0 \mathrm{~mL}, 247.0 \mathrm{mmol})$ was refluxed $12 \mathrm{~h}$, cooled, and concentrated in vacuo. The organic residue was dissolved in methylene chloride $(150 \mathrm{~mL})$, washed with water $(100 \mathrm{~mL})$ and brine $(100 \mathrm{~mL})$, dried $\left(\mathrm{Na}_{2} \mathrm{SO}_{4}\right)$ and concentrated in vacuo to give the formamide (18.33 g, 95\%) as an orange oil that was used directly in the next step. IR (Neat): 3370, 3070, 2980, 2800, 1690, 1630, $1610 \mathrm{~cm}^{-1} ;{ }^{1} \mathrm{H}$ NMR $\left(\mathrm{CDCl}_{3}\right): 2.68$ (t, 2H, $\left.J=12 \mathrm{~Hz}\right), 3.39(\mathrm{t}, 2 \mathrm{H}, J=$ l1Hz), 3.82 (s, 3H), 5.07 (s, 2H), 6.18 (bs, 1H), 6.69-6.75 (m, 3H), 7.34 (s, 5H), 7.98 (s, $1 \mathrm{H}) ;{ }^{13} \mathrm{C}$ $\left(\mathrm{CDCl}_{3}\right)$ ppm: 161.1, 149.7, 146.8, 137.1, 131.6, 128.4, 127.7, 127.2, 120.6, 114.3, 112.4, 71.1, 55.9, 39.1, 35.0.

6-Methoxy-7-benzyloxy-3,4-dihydroisoquinoline. Phosphorus pentachloride (10.51g, $50.0 \mathrm{mmol}$ ) was added slowly added to a stirred, cooled $\left(-78{ }^{\circ} \mathrm{C}\right)$ solution of the above formamide $(7.20 \mathrm{~g}, 25.0$ $\mathrm{mmol})$ in chloroform $(150 \mathrm{~mL})$. The reaction mixture was warmed to room temperature slowly, stirred $24 \mathrm{~h}$ and poured into cooled $\left(-78{ }^{\circ} \mathrm{C}\right)$ ether $(600 \mathrm{~mL})$. The precipitate was filtered, washed with ether ( $3 \times 100 \mathrm{~mL}$ ), dried and recrystallized from ethanol to give the $\mathrm{HCl}$ salt (4.31g, 56\%) as a yellow solid; mp $181-183^{\circ} \mathrm{C}$. The salt was partitioned between chloroform (50 mL) and 10\% $\mathrm{NaOH}$ 
(50 $\mathrm{mL}$ ), the aqueous phase was extracted once with chloroform $(30 \mathrm{~mL})$, the organic phases were combined, washed with brine $(100 \mathrm{~mL})$, dried $\left(\mathrm{Na}_{2} \mathrm{SO}_{4}\right)$ and concentrated in vacuo. Recrystallization from 5\% EtOAc/hexanes gave 3.65g (54\%) of a white solid; mp $181-183^{\circ} \mathrm{C}$; Methiodide mp 193-195 ${ }^{\circ}$; IR $\left(\mathrm{CHCl}_{3}\right): 1650,1620,1580 \mathrm{~cm}^{-1}$; ${ }^{1} \mathrm{H}$ NMR $\left(\mathrm{CDCl}_{3}\right): 2.64$ (t, $2 \mathrm{H}, J=$ $12 \mathrm{~Hz}$ ), 3.72 (t, 2H, $J=12 \mathrm{~Hz}), 3.91(\mathrm{~s}, 3 \mathrm{H}), 5.14$ (s, 2H), 6.69 (s, 1H), 6.85 (s, 1H), 7.40 (s, 5H), 8.16 (s, $1 \mathrm{H}) ;{ }^{13} \mathrm{C}\left(\mathrm{CDCl}_{3}\right): 157.9,150.4,145.3,135.3,128.8,126.9,126.3,125.7,119.9,111.7$, 109.2, 73.8, 69.7, 54.4, 45.6, 23.1. Methiodide Anal. Calc. for $\mathrm{C}_{18} \mathrm{H}_{20} \mathrm{INO}_{2}$ : C, 52.82; H, 4.92. Found: C, 52.69; H, 4.93.

6-Methoxy-7-benzyloxy-1,2,3,4-tetrahydroisoquinoline, (3). Sodium borohydride (0.56g, 15.0 mmol) was added to a stirred, cooled $\left(15^{\circ} \mathrm{C}\right)$ solution of the above $\mathrm{HCl}$ salt $(3.0 \mathrm{~g}, 10.0 \mathrm{mmol})$ in ethanol (25 mL). The reaction mixture was warmed to room temperature, stirred $3 \mathrm{~h}$, quenched with water $(10 \mathrm{~mL})$ and concentrated in vacuo to one-third the original volume. The residue was dissolved in chloroform (50 mL), washed with water (30 mL) and brine (30 mL), dried $\left(\mathrm{Na}_{2} \mathrm{SO}_{4}\right)$ and concentrated in vacuo. Recrystallization from $10 \%$ THF/ether gave $(2.05 \mathrm{~g}, 77 \%)$ of a white solid; mp $124-126{ }^{\circ} \mathrm{C}$ (lit. mp $125-126^{\circ} \mathrm{C}$ ). ${ }^{14}$

\section{General synthetic procedures}

General procedure A. Condensation of tetrahydroisoquinolines with the chiral oxazolines A solution of the tetrahydroisoquinoline (1 equivalent), the chiral auxiliary (1.1 equivalent) and a catalytic amount of $p$-toluenesulfonic acid, in benzene $(10 \mathrm{~mL} / \mathrm{eq})$ were refluxed $6-8 \mathrm{~h}$. The reaction mixture was then washed with saturated bicarbonate $(10 \mathrm{~mL} / \mathrm{eq})$ and brine $(10 \mathrm{~mL} / \mathrm{eq})$ solutions. The organic phase was dried $\left(\mathrm{Na}_{2} \mathrm{CO}_{3}\right)$ and concentrated in vacuo. The crude product was then purified by radial chromatography $\left(2 \% \mathrm{MeOH} / \mathrm{CH}_{2} \mathrm{Cl}_{2}\right)$, followed by bulb-to-bulb distillation from calcium hydride.

\section{General procedure B. Metalation and alkylation of tetrahydroisoquinolinyl-oxazolines}

The base, t-butyllithium (1.7M solution in pentane, 1.2 equivalents) was added slowly to a $0.2 \mathrm{M}$ solution of the tetrahydroisoquinolinyloxazoline (1 equivalent) in THF at $-78{ }^{\circ} \mathrm{C}$. The reaction mixture was stirred at $-78{ }^{\circ} \mathrm{C}$ for 330 minutes, cooled to $-100{ }^{\circ} \mathrm{C}$ and quenched with a $0.3 \mathrm{M}$ solution of the electrophile (1.5 equiv) in THF. The reaction temperature was maintained at $-100{ }^{\circ} \mathrm{C}$ for $30 \mathrm{~min}$ and then allowed to warm to room temperature slowly. The mixture was then quenched with brine $(10 \mathrm{~mL} / \mathrm{eq})$, the organic phase extracted with $\mathrm{CHCl}_{3}(10 \mathrm{~mL} / \mathrm{eq})$, washed with brine, dried $\left(\mathrm{Na}_{2} \mathrm{CO}_{3}\right)$ and concentrated in vacuo. The crude product was purified via radial chromatography (2\% $\mathrm{MeOH} / \mathrm{CH}_{2} \mathrm{Cl}_{2}$ ) and/or by kugelrohr distillation from calcium hydride.

\section{General procedure C. Removal of the chiral auxiliary}

A solution of the 1-alkyl-tetrahydroisoquinolyloxazoline (1 equiv), hydrazine hydrate (5 equiv) and p-toluenesulfonic acid in 95\% ethanol (10 mL/eq) was refluxed $6 \mathrm{~h}$. The reaction mixture was concentrated in vacuo, the residue dissolved in $\mathrm{CH}_{2} \mathrm{Cl}_{2}(10 \mathrm{~mL} / \mathrm{eq})$, washed with water $(5 \times 10$ $\mathrm{mL} / \mathrm{eq})$ and brine $(10 \mathrm{~mL} / \mathrm{eq})$, dried $\left(\mathrm{Na}_{2} \mathrm{CO}_{3}\right)$ and concentrated in vacuo. The crude product was then purified by radial chromatography $\left(5 \% \mathrm{MeOH} / \mathrm{CH}_{2} \mathrm{Cl}_{2}\right)$. 


\section{General procedure D. Optical purity determination via Pirkle column}

A solution of the l-alkyltetrahydroisoquinoline (1 equiv), 1-naphthoyl chloride (1.5 equiv) and triethylamine (3 equiv) in methylene chloride $(10 \mathrm{~mL} / \mathrm{eq})$ was stirred one-half hour at room temperature. The reaction mixture was diluted with methylene chloride $(20 \mathrm{~mL} / \mathrm{eq})$, washed with saturated bicarbonate $(10 \mathrm{~mL} / \mathrm{eq})$ and brine $(10 \mathrm{~mL} / \mathrm{eq})$, dried (anhy. $\left.\mathrm{K}_{2} \mathrm{CO}_{3}\right)$ and concentrated in vacuo. The crude product was purified by radial chromatography ( $\left.\% \mathrm{MeOH} / \mathrm{CH}_{2} \mathrm{Cl}_{2}\right)$. The naphthamide derivative was then subjected to HPLC analysis using a $R$-DNBPG Pirkle column, according to the published procedure. ${ }^{8}$ General conditions for each run were: solvent, 20 to $25 \%$ isopropanol in hexane; flow rate $2.0 \mathrm{~mL} / \mathrm{min}$; detection at $240 \mathrm{~nm}$.

\section{Synthesis of fragment (1)}

2-[4,5-Dihydro-4-((S)-1-methylethy1)2-oxazolyl]-6-methoxy-7-benzyloxy-1,2,3,4-

tetrahydroisoquinoline $(S-7)$. A solution of $3(1.0 \mathrm{~g}, 3.71 \mathrm{mmol})$ and ethoxyoxazoline $(S-6)(0.64$ g, $4.08 \mathrm{mmol}$ ) were reacted according to General procedure A. Recrystallization from hexanes afforded 79 (0.90 g, 64\%) as a white solid; mp 77-78 ${ }^{\circ} \mathrm{C}$; $[\alpha]_{D}^{20}-30.4$ (c=0.5, benzene); IR $\left(\mathrm{CHCl}_{3}\right)$ : 2920, 2860, 1660, 1625, $1610 \mathrm{~cm}^{-1}$; ${ }^{1} \mathrm{H}$ NMR $\left(\mathrm{CDC1}_{3}\right): 0.88$ (t, 6H, J = 10Hz), 1.64 (m, $\left.1 \mathrm{H}\right), 2.76$ (t, $2 \mathrm{H}, J=10 \mathrm{~Hz}), 3.60$ (t, 2H, $J=10 \mathrm{~Hz}), 3.84(\mathrm{~s}, 4 \mathrm{H}), 4.01-4.29(\mathrm{~m}, 2 \mathrm{H}), 4.42(\mathrm{~s}, 2 \mathrm{H}), 5.09$ (s, 2H), 6.61 (s, 2H), 7.38 (s, 5H); ${ }^{13} \mathrm{C}\left(\mathrm{CDCl}_{3}\right) \mathrm{ppm}$ : 160.8, 148.2, 146. 7, 137.1, 128.4, 127.7, 127.1, 126.8, 112.1, 112.0, 71.1, 70.4, 70.1, 56.0, 46.9, 42.8, 33.2, 28.1, 18.8, 17.5. Anal. Calc. for $\mathrm{C}_{23} \mathrm{H}_{28} \mathrm{~N}_{2} \mathrm{O}_{3}$ : C, 72.60; H, 7.42. Found: C, 72.67; H, 7.44

2-[4,5-Dihydro-4((S)-1-methylethyl)-2-oxazolyl]-(R)-1-(4-benzyloxybenzyl)-6-methoxy-7benzyloxy-1,2,3,4- tetrahydroisoquinoline (8). Isoquinolyloxazoline $S-7$ (0.20 g, $0.52 \mathrm{mmol})$, tertbutyllithiun $(0.37 \mathrm{~mL}, 0.63 \mathrm{mmol})$ and 4-benzyloxybenzyl chloride $(0.18 \mathrm{~g}, 0.79 \mathrm{mmol})$ were reacted according to General procedure $\mathrm{B}$. Radial chromatography (2.5\% $\mathrm{MeOH} / \mathrm{CH}_{2} \mathrm{Cl}_{2}$ ) gave 80 $(0.25 \mathrm{~g}, 88 \%)$ as a glass. IR $\left(\mathrm{CHCl}_{3}\right): 3370,3040,2980,1660,1630,1610 \mathrm{~cm}^{-1} ;{ }^{1} \mathrm{H} \mathrm{NMR}\left(\mathrm{CDC1}_{3}\right)$ : $0.84(\mathrm{~m}, 6 \mathrm{H}), 1.60(\mathrm{~m}, 1 \mathrm{H}), 2.60$ (m, 2H), 2.80 (m, 2H), 3.64 (m, 1H), 3.82 (s, 3H), 3.93-4.20 (m, 4H), 4.93 (s, 2H), 4.99 (s, 2H), 5.73 (m, 1H), 6.41 (s, 1H), 6.57 (s, 1H), 6.91 (m, 2H), 7.34 (bs, $12 \mathrm{H}) ;{ }^{13} \mathrm{C}\left(\mathrm{CDCl}_{3}\right)$ ppm: 160.0, 157.2, 148.3, 146.0, 136.8, 130.6, 129.9, 129.2, 128.2, 128.0,127.6,127.1, 126.0, 121.2, 114.4, 112.9, 111.6, 70.8, 69.6, 57.4, 55.7, 32.3, 18.1. HRMS calc. for $\mathrm{C}_{37} \mathrm{H}_{40} \mathrm{~N}_{2} \mathrm{O}_{4}: \mathrm{M}^{+}=576.2988$. Found $\mathrm{M}-\mathrm{H}^{+}=575.2919$.

(R)-1-(4-Benzyloxybenzyl)-6-methoxy-7-benzyloxy-1,2,3,4-tetrahydroisoquinoline. A solution of $8(0.69 \mathrm{~g}, 1.20 \mathrm{mmol})$ and hydrazine hydrate $(0.60 \mathrm{~mL}, 12.0 \mathrm{mmol})$ were reacted following General procedure $\mathrm{C}$. Radial chromatography $\left(7 \% \mathrm{MeOH} / \mathrm{CH}_{2} \mathrm{C1}_{2}\right)$ gave $0.46 \mathrm{~g}(82 \%)$ as a pale yellow oil that was used directly in the next step. IR (Neat): 3380, 3060, 2945, 1625, $1600 \mathrm{~cm}^{-1} ;{ }^{1} \mathrm{H}$ NMR $\left(\mathrm{CDC1}_{3}\right): 2.72$ (m, 2H), 2.89 (m, 3H), 3.82 (s, 5H), 5.03 (m, 5H), 6.59-6.67 (m, 2H), 6.97-7.05 (m, 2H), 7.36 (bs, 12H); ${ }^{13} \mathrm{C}\left(\mathrm{CDCl}_{3}\right)$ ppm: 157.3, 148.1, 145.9, 137.2, 136.9, 131.1, 130.4, 130.1, 128.3, 128.0, 127.7, 127.6, 127.2, 114.7, 112.7, 112.3, 71.2, 69.8, 56.6, 55.7, 41.5, 29.3. Following experimental guidelines given in General procedure $\mathrm{D}$, the major isomer was found to be $R$ (96:4 er). 
(R)-1-(4-Benzyloxybenzyl)-2-formyl-6-methoxy-7-benzyloxy-1,2,3,4-tetrahydro-isoquinoline

(9). Method A. A solution of the above secondary amine $(0.46 \mathrm{~g}, 1.0 \mathrm{mmol})$ and acetic formic anhydride (0.43 g, $5.0 \mathrm{mmol})$ in THF $(10 \mathrm{ml})$ was refluxed $6 \mathrm{~h}$, cooled and concentrated in vacuo. The residue was dissolved in methylene chloride $(25 \mathrm{~mL})$, washed with water $(25 \mathrm{~mL})$, saturated bicarbonate $(25 \mathrm{~mL})$ and brine $(25 \mathrm{~mL})$ solutions, dried $\left(\mathrm{Na}_{2} \mathrm{SO}_{4}\right)$ and concentrated in vacuo. Radial chromatography ( $\left.2 \% \mathrm{MeOH} / \mathrm{CH}_{2} \mathrm{Cl}_{2}\right)$ gave $9(0.41 \mathrm{~g}, 83 \%)$ as a yellow oil which was used directly in the following step. IR (Neat): 3060, 2960, 1690, 1630, $1600 \mathrm{~cm}^{-1} ;{ }^{1} \mathrm{H} \mathrm{NMR}\left(\mathrm{CDCl}_{3}\right): 2.65-3.10$ (m, 4H), 3.82 (s, 5H), 4.99 (s, 2H), 5.07 (s, 2H), 5.38 (m, IH), 6.59 (s, 2H), 6.91 (d, 2H, J = 8Hz), 7.36 (bs, 12H), 8.06 (s, 1H); ${ }^{13} \mathrm{C}\left(\mathrm{CDCl}_{3}\right) \mathrm{ppm}: 160.9,157.4,136.6,130.4,130.1,129.8,129.4$, 129.1, 128.1, 127.5, 127.0, 126.4, 114.7, 114.5, 114.3, 114.2, 111.8, 75.4, 69.5, 55.6, 40.5.

Method B. A solution of $8(0.54 \mathrm{~g}, 93.0 \mathrm{mmol})$ and acetic formic anhydride (1.64 g, $18.62 \mathrm{mmol})$ in THF (8 mL) was refluxed $18 \mathrm{~h}$, cooled and concentrated in vacuo. The residue was dissolved in chloroform $(50 \mathrm{~mL})$, washed with water $(50 \mathrm{~mL})$, saturated bicarbonate $(50 \mathrm{~mL})$ and brine $(50 \mathrm{~mL})$ solutions, dried $\left(\mathrm{Na}_{2} \mathrm{SO}_{4}\right)$ and concentrated in vacuo. Radial chromatography (2\% $\mathrm{MeOH} / \mathrm{CH}_{2} \mathrm{Cl}_{2}$ ) gave 9 (0.36 g, 79\%) as a yellow oil. Spectral data identical to that from method A.

(R)-1-(4-Benzyloxybenzyl)-2-methyl-6-methoxy-7-benzyloxy-1,2,3,4-tetrahydroisoquinoline.

The formamide 9 ( $0.29 \mathrm{~g}, 0.59 \mathrm{mmol})$ was added dropwise to a stirred suspension of LAH $(0.045 \mathrm{~g}$, $1.17 \mathrm{mmol})$ in THF $(5 \mathrm{~mL})$. The reaction mixture was refluxed $12 \mathrm{~h}$, cooled, diluted with ether (10 $\mathrm{mL})$ and quenched with water $(0.05 \mathrm{~mL}), 15 \% \mathrm{NaOH}(0.05 \mathrm{~mL})$ and water $(0.15 \mathrm{~mL})$. The solution was filtered, the filtrate dried $\left(\mathrm{Na}_{2} \mathrm{SO}_{4}\right)$ and concentrated in vacuo. Radial chromatography (2.5\% $\mathrm{MeOH} / \mathrm{CH}_{2} \mathrm{Cl}_{2}$ ) afforded $0.24 \mathrm{~g}(85 \%)$ of a pale yellow oil. $[\alpha]_{D}^{20}-37.6$ (c=0.9, $\mathrm{CHCl}_{3}$ ); IR (Neat): 3440, 3060, 2960, 2820, 1630, $1600 \mathrm{~cm}^{-1} ;{ }^{1} \mathrm{H}$ NMR $\left(\mathrm{CDCl}_{3}\right): 2.48$ (8, 3H), 2.66-3.03 (m, 4H), 3.60 (m, 2H), 3.80 (s, 3H), 3.99 (m, 1H), 4.77 (s, 2H), 4.97 (s, 2H), 6.08 (s, 1H), 6.55 (s, 1H), 6.89 (s, 2H), 7.31 (bs, 12H); ${ }^{13} \mathrm{C}\left(\mathrm{CDCl}_{3}\right)$ ppm: 157.2, 157.1, 147.8, 145.4, 137.1, 137.0, 131.9, 130.6, 128.8, 128.3, 127.9, 127.7, 127.4, 127.2, 127.1, 126.4, 126.3, 114.3, 113.8, 113.7, 111.7, 111.6, 70.7, 69.8, 64.6, 55.7, 46.7, 42.4, 25.4.

(R)-1-(3-Bromo-4-benzyloxybenzyl)-2-methyl-6-methoxy-7-benzyloxy-1,2,3,4-

tetrahydroisoquinoline (1). A solution of bromine $(0.033 \mathrm{~g}, 0.21 \mathrm{mmol})$ in glacial acetic acid (1 $\mathrm{mL})$ was added over $30 \mathrm{~min}$ to a stirred, cooled $\left(10^{\circ} \mathrm{C}\right)$ solution of the above compound $(0.10 \mathrm{~g}$, $0.21 \mathrm{mmol})$ in $8 \%$ acetic acid $(6 \mathrm{~mL})$. The reaction mixture was warmed to room temperature, stirred $1 \mathrm{~h}$ then made basic with $10 \% \mathrm{NaOH}$. The solution was extracted with ether ( $3 \times 20 \mathrm{~mL}$ ), the combined extracts washed with brine $(50 \mathrm{~mL})$, dried $\left(\mathrm{Na}_{2} \mathrm{SO}_{4}\right)$ and concentrated in vacuo. Radial chromatography (5\% $\left.\mathrm{MeOH} / \mathrm{CH}_{2} \mathrm{Cl}_{2}\right)$ afforded $1(0.083 \mathrm{~g}, 71 \%)$ as a yellow oil. This was converted to the tartrate by reaction with di-p-tolyltartaric acid $(0.058 \mathrm{~g}, 0.15 \mathrm{mmol})$ in acetone (2 $\mathrm{mL})$. The solution was refrigerated overnight, diluted with hexane $(1 \mathrm{~mL})$, the crystals filtered and recrystallized from methanol to give a white solid; mp $155-156{ }^{\circ} \mathrm{C}$ (lit. mp $\left.157.5-158{ }^{\circ} \mathrm{C}\right) .{ }^{10}[\alpha]_{D}^{20}-$ 82.3, $\mathrm{c}=1, \mathrm{CHCl}_{3}$ (lit. $\left.[\alpha]_{D}^{20}-84.6, \mathrm{c}=2.8, \mathrm{CHC1}_{3}\right){ }^{10}$ The salt was suspended in chloroform (10 $\mathrm{mL}$ ) and made alkaline with $10 \% \mathrm{NH}_{4} \mathrm{OH}$. The organic phase was washed with brine $(20 \mathrm{~mL})$, dried $\left(\mathrm{Na}_{2} \mathrm{SO}_{4}\right)$ and concentrated in vacuo to give $1(0.067 \mathrm{~g})$ as a pale yellow oil; $[\alpha]_{D}^{20}-40.92$, c $=3.35$, 
$\mathrm{CHCl}_{3}$ (lit. $[\alpha]_{D}^{20}-41.8, \mathrm{CHCl}_{3} ;{ }^{4}[\alpha]_{D}^{4}-43.0, \mathrm{c}=5.3$ in $\mathrm{CHCl}_{3} \cdot{ }^{10}$ ). IR (neat); 3060, 2960, 1630, 1600, $1525 \mathrm{~cm}^{-1}$; ${ }^{1} \mathrm{H}$ NMR $\left(\mathrm{CDCl}_{3}\right): 2.47$ (s, 3H), 2.65-2.80 (m, 2H), 2.95-3.15 (m, 2H), $3.58(\mathrm{t}$, $1 \mathrm{H}), 3.80$ (d, 2H), 3.83 (s, 3H), 4.78-4.90 (ABq, 2H, $J=12 \mathrm{~Hz}), 5.08$ (s, 2H), 6.13 (s, 1H), 6.55 (s, 1H), 6.72-6.87 (m, 2H), 7.23-7.44 (m, $11 \mathrm{H}) ;{ }^{13} \mathrm{C}\left(\mathrm{CDCl}_{3}\right) \mathrm{ppm}$ : 157.1, 147.9, 145.5, 137.2, 137.1, 132.2, 130.7, 129.1, 128.4, 128.3, 127.8, 127.6, 127.3, 127.2, 126.5, 114.4, 113.8, 111.7, 70.8, 67.0, 64.7, 55.8, 47.0, 42.5, 40.0, 25.6.

\section{2-[4,5-Dihydro-4-((S)-1-methylethyl)-2-oxazolyl]-(R)-1-(3-bromo-4-benzyloxy-benzyl)-6-}

methoxy-7-benzyloxy-1,2,3,4-tetrahydroisoquinoline (10). The isoquinolyloxazoline $S-7$ (0.75 g, $1.97 \mathrm{mmol})$, tert-butyllithium (1.62 ml, $2.76 \mathrm{mmol})$ and 3-bromo-4-benzyloxybenzyl chloride (0.92 g, $2.96 \mathrm{mmol})$ were reacted according to General Procedure B. Radial chromatography (2.0\% $\mathrm{MeOH} / \mathrm{CH}_{2} \mathrm{C1}_{2}$ ) gave 10 (0.97 g, 75\%) as a viscous yellow oil. IR (Neat): 3000, 2950, 1680, 1630, $1600 \mathrm{~cm}^{-1}$; ${ }^{1} \mathrm{H}$ NMR $\left(\mathrm{CDCl}_{3}\right): 0.84(\mathrm{~m}, 6 \mathrm{H}), 1.45$ (m, 1H), 2.50-2.93 (m, 4H), 3.58 (m, 1H), 3.76 (s, 3H), 3.95-4.27 (m, 4H), 4.89 (s, 2H), 5.03 (s, 2H), 5.83 (m, 1H), 6.32 (s, 1H), 6.53 (s, 1H), 6.856.81 (m, 2H), 7.30 (bs, 10H), 7.81 (s, $1 \mathrm{H}) ;{ }^{13} \mathrm{C}\left(\mathrm{CDCl}_{3}\right) \mathrm{ppm:} \mathrm{160.1,} \mathrm{153.3,} \mathrm{148.2,} \mathrm{145.9,} \mathrm{136.9,}$ 136.4, 134.3, 132.5, 129.6, 128.3, 127.9, 127.6, 127.0, 126.7, 113.3, 113.1, 111.7, 70.9, 70.6, 69.6, 56.9, 55.8, 33.1, 17.6. HRMS calc. for $\mathrm{C}_{37} \mathrm{H}_{39} \mathrm{BrN}_{2} \mathrm{O}_{4}: \mathrm{M}^{+}=654.2093$. Found $\mathrm{M}+=654.2060$.

\section{(R)-1-(3-Bromo-4-benzyloxybenzyl)-2-formyl-6-methoxy-7-benzyloxy-1,2,3,4-tetrahydroiso-}

quinoline (11). A solution of $10(0.90 \mathrm{~g}, 1.37 \mathrm{mmol})$ and hydrazine hydrate $(0.69 \mathrm{ml}, 13.73 \mathrm{mmol})$ were reacted following General Procedure C. Radial chromatography (7\% $\mathrm{MeOH} / \mathrm{CH}_{2} \mathrm{Cl}_{2}$ ) gave $0.61 \mathrm{~g}$ (81 \%) of a pale yellow oil which was used directly in the next step. IR (Neat): 3310, 3030, 2980, 2860, 1630, $1600 \mathrm{~cm}^{-1}$. Following experimental guidelines given in General Procedure D, the major isomer was found to be $R(96: 4 \mathrm{er})$. A solution of this amine $(0.60 \mathrm{~g}, 1.10 \mathrm{mmol})$ and acetic formic anhydride $(0.50 \mathrm{~g}, 5.68 \mathrm{mmol})$ was refluxed $6 \mathrm{~h}$, cooled and concentrated in vacuo. The residue obtained was dissolved in methylene chloride $(30 \mathrm{~mL})$, washed with water $(30 \mathrm{~mL})$, saturated bicarbonate $(30 \mathrm{~mL})$ and brine $(30 \mathrm{~mL})$ solutions, dried $\left(\mathrm{Na}_{2} \mathrm{SO}_{4}\right)$ and concentrated in vacuo. Radial chromatography (2.0\% $\left.\mathrm{MeOH} / \mathrm{CH}_{2} \mathrm{Cl}_{2}\right)$ gave $11(0.52 \mathrm{~g}, 82 \%)$ as a dark yellow oil that was used directly in the next step. IR (Neat): 3060, 3010, 2980, 2880, 1690, 1630, $1600 \mathrm{~cm}^{-1}$; ${ }^{1} \mathrm{H}$ NMR $\left(\mathrm{CDCl}_{3}\right)$ : 2.58-2.95 (m, 4H), 3.80 (8, 5H), 4.91 (s, 2H), 5.03 (s, 2H), 5.40 (m, 1H), 6.32 (s, $1 \mathrm{H}), 6.54$ (s, 1H), 6.83-6.97 (m, 2H), 7.35 (bs, $10 \mathrm{H}), 7.67$ (s, $1 \mathrm{H}), 8.06$ (s, $1 \mathrm{H}) ;{ }^{13} \mathrm{C}\left(\mathrm{CDCl}_{3}\right) \mathrm{ppm}$ : 161.1, 153.6, 148.9, 148.4, 146.4, 146.2, 136.8, 136.7, 136.2, 131.4, 131.1, 121.5, 128.3, 127.6, 127.1, 127.0, 126.8, 126.6, 126.3, 125.8, 113.6, 113.0, 112.4, 111.8, 71.1, 70.6, 58.1, 55.8.

\section{(R)-1-(3-Bromo-4-benzyloxybenzyl)-2-methyl-6-methoxy-7-benzyloxy-1,2,3,4-}

tetrahydroisoquinoline (1). A solution of $11(0.50 \mathrm{~g}, 0.87 \mathrm{mmol})$ in THF (2 mL) was added dropwise to a stirred suspension of LAH $(0.033 \mathrm{~g}, 0.87 \mathrm{mmol})$ in THF $(10 \mathrm{~mL})$. The reaction mixture was stirred $15 \mathrm{~min}$ at room temperature, refluxed $14 \mathrm{~h}$, cooled, diluted with ether $(10 \mathrm{~mL})$ and quenched with water $(0.03 \mathrm{~mL}), 15 \% \mathrm{NaOH}(0.03 \mathrm{~mL})$ and water $(0.09 \mathrm{~mL})$. The mixture was then filtered and the filtrate concentrated in vacuo. Radial chromatography $\left(2.0 \% \mathrm{MeOH} / \mathrm{CH}_{2} \mathrm{Cl}_{2}\right)$ gave $1(0.43 \mathrm{~g}, 88 \%)$ as a pale yellow oil. The tartrate salt was prepared following the procedure outlined previously; mp $155-156{ }^{\circ} \mathrm{C}$ (lit. mp $\left.157.5-158^{\circ} \mathrm{C}\right) .{ }^{10}[\alpha]_{D}^{20}-83.11$ (c $\left.=1.0, \mathrm{MeOH}\right)$. Neutralization of the salt with $\mathrm{NH}_{4} \mathrm{OH}$ afforded $1(0.353 \mathrm{~g})$ as a yellow oil. $[\alpha]_{D}^{20}-41.44, \mathrm{c}=3.35$, 
$\mathrm{CHCl}_{3}$ (lit. $[\alpha]_{D}^{20}-41.8, \mathrm{CHCl}_{3} ;{ }^{4}[\alpha]_{D}^{4}-43.0, \mathrm{c}=5.3$ in $\mathrm{CHCl}_{3}{ }^{10}$ ). NMR spectral data were identical to that obtained previously.

\section{Synthesis of fragment (2)}

2-[4,5-Dihydro-4-((R)-1-methylethyl)-2-oxazolyl]-6-methoxy-7-benzyloxy-1,2,3,4-

tetrahydroisoquinoline $(\boldsymbol{R}-7)$. A solution of $3(1.0 \mathrm{~g}, 3.71 \mathrm{mmol})$ and $R-6(0.64 \mathrm{~g}, 4.08 \mathrm{mmol})$ were reacted following General Procedure A. The viscous residue obtained was dissolved in hot hexanes and slowly cooled to afford $R-7$ (1.14 g, 81 \%) of a white solid; mp $75-77^{\circ} \mathrm{C}$. $[\alpha]_{D}^{20}+29.6$ (c $=0.5$, benzene). Spectral data identical to $S-7$.

2-[4,5-Dihydro-4-((R)-1-methylethyl)-2-oxazolyl]-(S)-1-(4-methoxymethoxybenzyl)-6-methoxy7-benzyloxy-1,2,3,4-tetrahydroisoquinoline (12). Isoquinolyloxazoline $R-7$ (0.75 g, $1.97 \mathrm{mmol})$, tert-butyllithium (1.51 mI, $2.56 \mathrm{mmol})$ and 4-methoxymethoxybenzyl chloride (0.51 g, $2.76 \mathrm{mmol})$ were reacted according to General Procedure B. Radial chromatography $\left(2.5 \% \mathrm{MeOH} / \mathrm{CH}_{2} \mathrm{Cl}_{2}\right.$ ) gave 12 (0.84 g, 84\%) as a viscous yellow oil. IR (Neat): 3000, 2950, 1680, 1630, $1600 \mathrm{~cm}^{-1} ;{ }^{1} \mathrm{H}$ NMR (CDCl $): 0.84(\mathrm{~m}, 6 \mathrm{H}), 1.56(\mathrm{~m}, 1 \mathrm{H}), 2.72-2.97(\mathrm{~m}, 4 \mathrm{H}), 3.39$ (s, 3H), $3.58(\mathrm{~m}, 1 \mathrm{H}), 3.82$ (s, 3H), 3.95-4.27 (m, 4H), 4.89 (s, 2H), 5.09 (s, 2H), 5.83 (m, 1H), 6.32 (s, 1H), $6.55(\mathrm{~s}, 1 \mathrm{H}), 6.95$ (m, 2H),7.32 (bs, 7H); ${ }^{13} \mathrm{C}\left(\mathrm{CDCl}_{3}\right) \mathrm{ppm}:$ 160.2, 155.6, 148.2, 145.8, 136.9, 130.6, 129.6, 129.0, 128.2, 127.7, 127.5, 127.0, 126.4, 115.8, 113.1, 111.7, 94.3, 70.8, 70.3, 55.6, 32.7, 18.3, 17.3. HRMS calc. for $\mathrm{C}_{32} \mathrm{H}_{35} \mathrm{~N}_{2} \mathrm{O}_{5}: \mathrm{M}^{+}=530.2781$, Found: $\mathrm{M}-\mathrm{H}^{+} 529.2726$

(S)-1-(4-Methoxymethoxybenzyl)-6-methoxy-7-benzyloxy-1,2,3,4-tetrahydro-isoquinoline. A solution of $12(0.65 \mathrm{~g}, 1.22 \mathrm{mmol})$ and hydrazine hydrate $(0.60 \mathrm{~mL}, 12.25 \mathrm{mmol})$ were reacted following General Procedure C. Radial chromatography (7\% $\mathrm{MeOH} / \mathrm{CH}_{2} \mathrm{Cl}_{2}$ ) gave $0.41 \mathrm{~g}(81 \%)$ of a pale yellow oil that was used directly in the next step. IR (Neat): 3310, 3030, 2980, 2860, 1630, $1600 \mathrm{~cm}^{-1} ;{ }^{1} \mathrm{H}$ NMR $\left(\mathrm{CDCl}_{3}\right):$ 2.70-2.80 (m, 5H), 3.39 (s, 3H), 3.77 (s, 5H), 4.50 (m, 1H), 5.01 (s, 2H), 5.09 (s, 2H), 6.57-6.70 (m, 2H), 7.01 (s, 2H), 7.33 (bs, 7H); ${ }^{13} \mathrm{C}\left(\mathrm{CDCl}_{3}\right) \mathrm{ppm}: 155.0,147.4$, 145.2, 136.6, 131.5, 129.7, 129.5, 127.5, 127.3, 126.8, 126.5, 115.5,115.2, 112.1, 111.7, 93.5, 70.4, 54.9, 47.3, 39.9, 29.9. Following experimental guidelines given in General Procedure D, the major isomer was found to be $S$ (97:3 er).

(S)-1-(4-Methoxymethoxybenzyl)-2-formyl-6-methoxy-7-benzyloxy-1,2,3,4-

tetrahydroisoquinoline (13). A solution of the above compound $(0.20 \mathrm{~g}, 0.48 \mathrm{mmol})$ and acetic formic anhydride $(0.21 \mathrm{~g}, 2.38 \mathrm{mmol})$ was refluxed $6 \mathrm{~h}$, cooled and concentrated in vacuo. The residue obtained was dissolved in methylene chloride $(30 \mathrm{~mL})$, washed with water $(30 \mathrm{~mL})$, saturated bicarbonate $(30 \mathrm{~mL})$ and brine $(30 \mathrm{~mL})$ solutions, dried $\left(\mathrm{Na}_{2} \mathrm{SO}_{4}\right)$ and concentrated in vacuo. Radial chromatography (2.5\% $\left.\mathrm{MeOH} / \mathrm{CH}_{2} \mathrm{C1}_{2}\right)$ gave $13(0.202 \mathrm{~g}, 95 \%)$ as a pale yellow oil which was used directly in the following step. $[\alpha]_{D}^{20}+39.0$ (c = 2.02, $\mathrm{CHCl}_{3}$ ). IR (Neat): 3060, 3010, 2980, 2880, 1690, 1630, $1600 \mathrm{~cm}^{-1} ;{ }^{1} \mathrm{H}$ NMR $\left(\mathrm{CDCl}_{3}\right)$ : 2.66-3.03 (m, 4H), 3.45 (s, $\left.3 \mathrm{H}\right), 3.82$ (s, 5H), 5.09 (s, 2H), 5.13 (s, 2H), 5.40 (m, IH), 6.61 (s, 2H), 6.95 (d, 2H, J = 8Hz), 7.36 (bs, 7H), $8.10(\mathrm{~s}, \mathrm{IH})$.

(S)-1-(4-Methoxymethoxybenzyl)-2-methyl-6-methoxy-7-benzyloxy-1,2,3,4-

tetrahydroisoquinoline. A solution of $13(0.20 \mathrm{~g}, 0.45 \mathrm{mmol})$ in THF (3 mL) was added dropwise 
to a stirred suspension of LAH $(0.025 \mathrm{~g}, 0.67 \mathrm{mmol})$ in THF $(10 \mathrm{~mL})$. The reaction mixture was stirred $15 \mathrm{~min}$ at room temperature, refluxed $14 \mathrm{~h}$, cooled, diluted with ether $(10 \mathrm{~mL})$ and quenched with water $(0.025 \mathrm{~mL}), 15 \% \mathrm{NaOH}(0.025 \mathrm{~mL})$ and water $(0.075 \mathrm{~mL})$. The mixture was then filtered and the filtrate concentrated in vacuo. Radial chromatography $\left(2.5 \% \mathrm{MeOH} / \mathrm{CH}_{2} \mathrm{Cl}_{2}\right)$ gave $0.15 \mathrm{~g}(80 \%)$ as a pale yellow oil which was used directly in the following step. $[\alpha]_{D}^{20}+39.79$ (c = 3.75, $\mathrm{CHCl}_{3}$ ); IR (Neat): 3060, 2980, 2860, 2810, 1630, $1525 \mathrm{~cm}^{-1} ;{ }^{1} \mathrm{H}$ NMR $\left(\mathrm{CDCl}_{3}\right): 2.50$ (s, 3H), 2.66-3.03 (m, 4H), 3.19 (m, 2H), 3.43 (s, 3H), 3.64 (m, 1H), 3.84 (s, 3H), 4.81 (s, 2H), 5.13 (s, 2H), 6.10 (s, 1H), 6.57 (s, 1H), 6.95-7.03 (m, 2H), 7.32 (s, 7H); ${ }^{13} \mathrm{C}\left(\mathrm{CDCl}_{3}\right) \mathrm{ppm}: 155.5,147.9,145.5$, 137.3, 133.2, 130.6, 129.1, 128.3, 127.5, 127.1, 126.5, 115.9, 113.8, 111.7, 94.5, 70.7, 64.7, 55.8, 46.9, 42.5, 40.0, 25.5.

(S)-1-(4-Hydroxybenzyl)-2-methyl-6-methoxy-7-benzyloxy-1,2,3,4-tetrahydro-isoquinoline (2). A solution of the above compound $(0.075 \mathrm{~g}, 0.17 \mathrm{mmol})$ and $18 \% \mathrm{HCl}(0.9 \mathrm{~mL})$ in $50 \%$ i-PrOH/THF was stirred at room temperature $14 \mathrm{~h}$, made alkaline with concentrated $\mathrm{NH}_{4} \mathrm{OH}$ and concentrated in vacuo. The residue obtained was partitioned between methylene chloride $(10 \mathrm{~mL})$ and water $(10 \mathrm{~mL})$, the aqueous phase was separated, extracted with methylene chloride $(2 \times 10$ $\mathrm{mL})$, the organic extracts were combined, washed with brine $(25 \mathrm{~mL})$, dried $\left(\mathrm{Na}_{2} \mathrm{SO}_{4}\right)$, and concentrated in vacuo. Radial chromatography (5\% $\left.\mathrm{MeOH} / \mathrm{CH}_{2} \mathrm{Cl}_{2}\right)$ gave $2(0.048 \mathrm{~g}, 73 \%)$ as a pale yellow oil $[\alpha]_{D}^{16}+129.7$, c $=2.5$, MeOH (lit. $[\alpha]_{D}^{15}+135.5$ in MeOH). ${ }^{15}$ IR (Neat): 3300, 3040, 2960, 2810, 1635, 1610, $1530 \mathrm{~cm}^{-1}$; ${ }^{1} \mathrm{H}$ NMR (400 MHz, $\mathrm{CDCl}_{3}$ ): 2.49 (s, 3H), 2.57-2.72 (m, 2H), 2.75-2.90 (m, 2H), 3.00-3.25 (m, 2H), 3.67 (t, 1H), $3.82(\mathrm{~s}, 3 \mathrm{H}), 4.74-4.85(\mathrm{ABq}, 2 \mathrm{H}, J=12 \mathrm{~Hz})$, 6.06 (s, $1 \mathrm{H}), 6.56(\mathrm{~s}, 1 \mathrm{H}), 6.65(\mathrm{~d}, 2 \mathrm{H}, J=8 \mathrm{~Hz}), 6.84(\mathrm{~d}, 2 \mathrm{H}, J=8 \mathrm{~Hz}), 7.20-7.45(\mathrm{~m}, 5 \mathrm{H}) ;{ }^{13} \mathrm{C}$ NMR $\left(\mathrm{CDCl}_{3}\right)$ ppm: 154.8, 148.1, 145.7, 137.2, 130.7, 130.6, 128.6, 128.4, 127.6, 127.3, 125.9, 115.4, 114.0, 111.8, 70.8, 64.8, 55.9, 46.2, 42.0, 40.2, 24.7.

\section{References and Notes}

1. Proskurnina, N. F.; Orekhoff, A. P. Bull. Soc. Chim. Fr. 1938, 5, 1357.

2. Tomita, M.; Kugo, T. Yakugaku Zasshi 1957, 77, 1075.

3. Dehaussy, H.; Tits, M.; Angenot, L. Planta Med. 1983, 49, 25.

4. Kametani, T.; Iida, H.; Sakurai, K.; Kano, S.; Ihara, M. Chem. Pharm. Bull. 1969, 17, 2120.

5. Kametani, T.; Iida, H.; Sakurai, K. J. Chem. Soc. C 1969, 500.

6. (a) Meyers, A. I. Aldrichimica Acta 1985, 18, 59; (b) Highsmith, T. K.; Meyers, A. I. In Advances in Heterocyclic Natural Product Synthesis; Pearson, W. H., Ed.; JAI: Greenwich, CT, 1991; Vol. 1, p 95; (c) Meyers, A. I. Tetrahedron 1992, 48, 2589.

7. (a) Gawley, R. E.; Hart, G.; Goicoechea-Pappas, M.; Smith, A. L. J. Org. Chem. 1986, 51, 3076; (b) Rein, K.; Goicoechea-Pappas, M.; Anklekar, T. V.; Hart, G. C.; Smith, G. A.; Gawley, R. E. J. Am. Chem. Soc. 1989, 111, 2211.

8. Pirkle, W. H.; Welch, C. J.; Mahler, G. S.; Meyers, A. I.; Fuentes, L. M.; Boes, M. J. Org. Chem. 1984, 49, 2504. 
9. This surprising transformation was discovered by accident when formylation with acetic formic anhydride was conducted on a mixture of the secondary amine produced after only partial removal of the oxazoline auxiliary.

10. Kametani, T.; Takano, S.; Masuko, K. Yakugaku Zasshi 1966, 86, 976.

11. Farkas, L.; Wolfner, A.; Olechnow.V Acta Chim. Acad. Sci. Hung. 1972, 74, 367.

12. Kessar, S. V.; Jogi, R. R.; Rampal, A. L.; Kumar, K. Indian J. Chem. 1964, 2, 240.

13. Falco, M. R.; Vries, J. X. D.; Marchell.E; Lorenzo, H. C. D.; Mann, G. Tetrahedron 1972, 28, 5999.

14. Hara, H.; Hoshino, O.; Umezawa, B. Chem. Pharm. Bull. 1985, 33, 2705.

15. Kametani, T.; Yagi, H. Chem. Pharm. Bull. 1967, 15, 1283. 